\title{
A probabilistic assessment of climate change impacts on yield and nitrogen leaching from winter wheat in Denmark
}

\author{
C. D. Børgesen and J. E. Olesen \\ Aarhus University, Department of Agroecology and Environment, 8830 Tjele, Denmark \\ Received: 9 February 2010 - Revised: 21 July 2011 - Accepted: 31 August 2011 - Published: 23 September 2011
}

\begin{abstract}
Climate change will impact agricultural production both directly and indirectly, but uncertainties related to likely impacts constrain current political decision making on adaptation. This analysis focuses on a methodology for applying probabilistic climate change projections to assess modelled wheat yields and nitrate leaching from arable land in Denmark. The probabilistic projections describe a range of possible changes in temperature and precipitation. Two methodologies to apply climate projections in impact models were tested. Method A was a straightforward correction of temperature and precipitation, where the same correction was applied to the baseline weather data for all days in the year, and method B used seasonal changes in precipitation and temperature to correct the baseline weather data. Based on climate change projections for the time span 2000 to 2100 and two soil types, the mean impact and the uncertainty of the climate change projections were analysed. Combining probability density functions of climate change projections with crop model simulations, the uncertainty and trends in nitrogen $(\mathrm{N})$ leaching and grain yields with climate change were quantified. The uncertainty of climate change projections was the dominating source of uncertainty in the projections of yield and $\mathrm{N}$ leaching, whereas the methodology to seasonally apply climate change projections had a minor effect. For most conditions, the probability of large yield reductions and large $\mathrm{N}$ leaching losses tracked trends in mean yields and mean $\mathrm{N}$ leaching. The impacts of the uncertainty in climate change were higher for loamy sandy soil than for sandy soils due to generally higher yield levels for loamy sandy soils. There were large differences between soil types in response to climate change, illustrating the importance of including soil information for regional studies of climate change impacts on cropping systems.
\end{abstract}

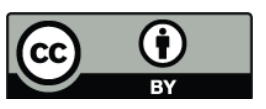

Correspondence to: C. D. Børgesen (christen.borgesen@agrsci.dk)

\section{Introduction}

Biophysical processes of agroecosystems are strongly affected by environmental conditions. The projected increases in greenhouse gases will affect agroecosystems either directly (primarily by increasing photosynthesis at higher $\mathrm{CO}_{2}$ concentrations; Long et al., 2006) or indirectly via effects on climate (e.g., temperature and precipitation affecting several aspects of ecosystem functioning, Olesen and Bindi, 2002). The exact responses depend on the sensitivity of the particular ecosystem and on the relative changes in the controlling factors.

Many studies have assessed effects of climate change (CC) on agricultural productivity in Europe (e.g., Harrison et al., 2000; Maracchi et al., 2005; Olesen et al., 2007, 2011; Challinor et al., 2009). Much fewer studies have attempted to quantify the effect of the uncertainty of the climate change projections on crop production. Such assessments are needed to properly identify the changes required to agricultural policy to account for CC.

Increasing the atmospheric $\mathrm{CO}_{2}$ concentration stimulates yield of $\mathrm{C}_{3}$ crops and to a lesser extent $\mathrm{C}_{4}$ crops (Fuhrer, 2003). However, recent estimates of the yield benefit from increasing $\mathrm{CO}_{2}$ are smaller than earlier ones (Ainsworth and Long, 2005; Tubiello et al., 2007), and the average annual increase over the next decades is marginal compared with what has been achieved through conventional crop management and breeding (Berntsen et al., 2006).

Increasing temperatures affect crops primarily via plant development. With warming, active growth starts earlier, plants develop faster, and the potential growing season is extended. This may have the greatest effect in colder regions. However, increased temperatures reduce crop duration. In wheat, an increase by $1^{\circ} \mathrm{C}$ during grain filling has been found to reduce the length of the grain-filling phase by $5 \%$, and yield declines by a similar amount (Olesen et al., 2000; Kristensen et al., 2011). The effect of increased temperature

Published by Copernicus Publications on behalf of the European Geosciences Union. 
leading to yield reductions will often be more than counterbalanced by the effect of increased $\mathrm{CO}_{2}$ on crop photosynthesis. For moderate changes in temperature and rainfall, the combination of both climate and $\mathrm{CO}_{2}$ effects will lead to small to moderate yield increases compared with yields simulated for the present situation (Ghaffari et al., 2002; van Ittersum et al., 2003).

Climate changes also have an impact on some environmental aspects of crop production. Nitrate that leaching from farmland, under current climatic conditions, has a large impact on the aquatic environment and on the natural life in the aquatic ecosystems (Kronvang et al., 2005). The risk is especially high where field drainage is through tile drains. Nitrate leaching from the root zone is a function of the concentration of mineral nitrogen $(\mathrm{N})$ in the soil water and the amount of excess water percolating through the soil profile. Large amounts of precipitation during autumn and winter increase the percolation rates, which increase nitrate leaching (Simmelsgaard, 1998) to the level where the nitrate concentrations are diluted. Temperature and radiation affect soil temperature, which in turn influences the mineralization of soil organic N (Turner and Henry, 2009; Thomsen et al., 2010). High mineralization rates in autumn and winter, combined with little crop $\mathrm{N}$ uptake and high percolation, will increase the risk of nitrate leaching. Nitrate leaching is also strongly dependent on crop rotation, crop management and $\mathrm{N}$ fertilization rate, and CC effects on these factors will, therefore, also affect $\mathrm{N}$ leaching (Jeppesen et al., 2011).

Coupled Atmosphere-Ocean General Circulation Models (AOGCMs) are widely used for CC projections on both global and regional scales (Mearns et al., 2001). Different methods to ascertain the uncertainty in projections of key climate parameters have been reported (Murphy et al., 2007, 2009). In our analysis, we use a probabilistic approach to impact assessment, in addition to a methodological analysis of uncertainties associated with applying climate change projections. Having a probabilistic description means that impacts can be expressed in terms of the risk of certain outcomes being exceeded at certain times in the future, which may be applied to analysing probability of having crop yields that are too low to be economically viable (Luo et al., 2007). However, as argued by Olesen et al. (2007), the uncertainties of the methods used to apply climate model output can play a larger role than the uncertainty associated with the different GCM or regional climate model (RCM) projections.

The aim of this study is to propose and evaluate a methodology to estimate mean effects and the uncertainties associated with probabilistic projections of $\mathrm{CC}$ on crop production and $\mathrm{N}$ leaching. There are additional uncertainties associated with the impact model used, but this is not included here. The specific objectives are (i) to develop a comprehensive method for analysing the effect of probabilistic projected $\mathrm{CC}$ on winter wheat yields and $\mathrm{N}$ leaching; (ii) obtaining the uncertainty in projections and the probabilities of exceeding critical thresholds of $\mathrm{N}$ leaching and wheat yields based on the uncertainty of CC projections representing the time span 2000 to 2100 . The study of Harris et al. (2010) provided $\mathrm{CC}$ probabilistic projections for the analysis from an emulator that samples the uncertainty space on a regional scale $(300 \times 300 \mathrm{~km}$ grid scale $)$ and produces stochastic estimates of temperature and precipitation change.

\section{Materials and methods}

\subsection{Crop model}

To obtain nitrate leaching and crop yield response surfaces, we used the soil-water-crop-atmosphere model Daisy (Hansen et al., 1991; Abrahamsen and Hansen, 2000). The model is a one-dimensional mechanistic and deterministic model, simulating crop and soil processes as affected by environmental conditions. The model simulates the water balance, $\mathrm{N}$ balance and losses, soil organic matter turnover and crop growth and yield from information on soil, weather and management. The model has been validated on independent datasets with good results (de Willegen, 1991; Diekkrüger et al., 1995; Smith et al., 1997).

The parameterisation of the Daisy soil organic matter (SOM) model was revised based on the carbon content of Danish long-term field experiments (Bruun et al., 2003). The revised parameterisation takes into account higher $\mathrm{C}$ input to soil (includes rhizodeposition), and the turnover rates of soil $\mathrm{C}$ are adjusted in order to reflect especially the medium-term turnover observed experimentally. This revised parameterisation better resembles the trends in soil organic matter content of Danish arable farming systems than the original parameterisation (Olesen et al., 2004) and was, therefore, used in the present study.

The photosynthesis in Daisy is calculated using a light saturation response curve. However, the effect of $\mathrm{CO}_{2}$ concentration is not included in the standard Daisy model. $\mathrm{As}^{\mathrm{CO}_{2}}$ concentration is linked with $\mathrm{CC}$ and affects both photosynthesis and transpiration, we have changed the Daisy parameters controlling: (1) Saturated photosynthesis rate; (2) N concentrations of all vegetative plant organs; and (3) Potential transpiration. Appendix 1 describes in detail the changes in parameterisation dealing with the effects of changes in $\mathrm{CO}_{2}$ concentration.

\subsection{Projected climate change and meteorological data}

Daily meteorological data are needed as input in the Daisy simulations. Daily meteorological (observed) data interpolated to a $50 \times 50 \mathrm{~km}$ grid across Europe were extracted for the period 1976-2005 from the MARS-STAT database (Genovese, 2004). The grid box values for the grid covering northern Fuenen in the centre of Denmark were used as baseline in this study, and for producing meteorological datasets characterising the variation of projected future climatic conditions. The data include global radiation, air 


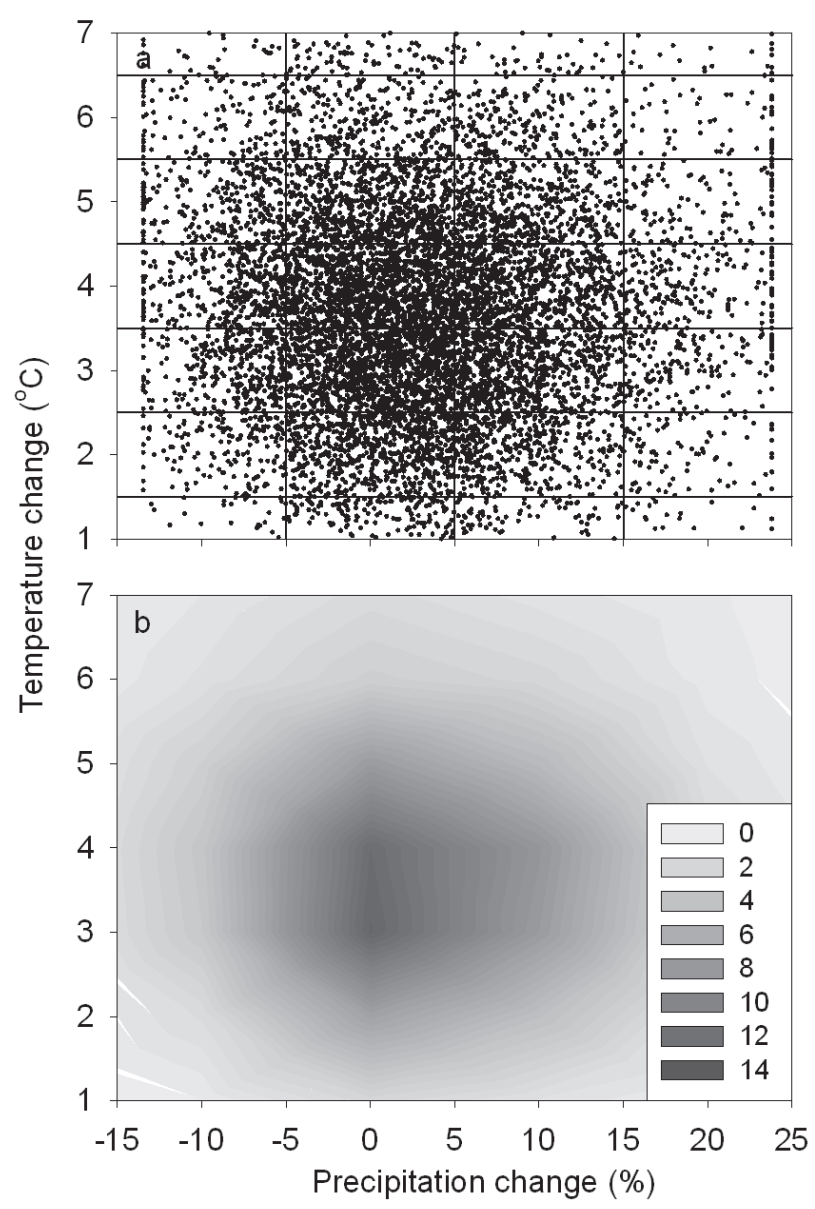

Fig. 1. Projections of annual mean change in temperature and precipitation for Denmark for the years 2061-2080 for the A1B emission scenario (a), and the joint probability density function (PDF) obtained based on number of observations within each $1^{\circ} \mathrm{C} \times 10 \%$ cell (b). The scale for shading in (b) shows the percentage of observations in each of the $1^{\circ} \mathrm{C} \times 10 \%$ cells (data from Harris et al., 2010).

temperature, precipitation, wind speed and humidity. Reference evapotranspiration was calculated using the Penman equation (Penman, 1956). Projected CC for the A1B emission scenario relative to 1961-1990 was provided by Harris et al. (2010) representing uncertainties among and within GCM projections of climate change. Gridded European data on a $300 \times 300 \mathrm{~km}$ spacing were available, representing periods of 20 yr: 2001-2020, 2011-2030, .., 2081-2100. The single datasets consist of 10000 "observations" of projected changes in precipitation $(\%)$ and temperature $\left({ }^{\circ} \mathrm{C}\right)$, sampled across the uncertainty space of GCM projections. Harris et al. (2010) corrected the data lying outside the 1st and 99th percentiles of temperature and precipitation change to values equal to the 1 st and 99th percentiles, respectively. This was done to remove the effect of distant outliers, which have reduced confidence.
Two types of projection data were available: mean projections on an annual timescale and mean projections on a seasonal timescale (four seasons; winter (Dec-Feb, DJF), spring (Mar-May, MAM), summer (Jun-Aug, JJA) and autumn (Sep-Nov, SON)). Figure 1a shows an example of the 10000 projected changes in annual mean temperature and precipitation for Denmark for the period 2061-2080. Based on these projections, a joint Probability Density Function (PDF) was generated by first obtaining the probability of CC for each grid cell (of dimensions $1^{\circ} \mathrm{C} \times 10 \%$ change in precipitation) and then using these data as input in the interpolation of the contour plot of the joint PDF (Fig. 1b). The PDF contour plot gives a better visual impression of the distribution of projected changes (variability) than Fig. 1a and an improved appreciation of the mean change in precipitation and temperature.

Two different methodologies - method A (annual projected $\mathrm{CC}$ ) and B (seasonal projected $\mathrm{CC}$ ) - were tested for applying $\mathrm{CC}$ projections in the simulation of grain yield and $\mathrm{N}$ leaching. For both methods the range in $\mathrm{CC}$ presented in the 10000 observations was used in the generation of matrices of changes in temperature and precipitation. For each of the methods A and B the matrix consisted of 42 meteorological datasets. Each dataset was generated by systematically changing temperature and precipitation of the original MARS-STAT dataset. We used steps of $+1^{\circ} \mathrm{C}$ from the minimum to the maximum $\left(0\right.$ to $\left.+7^{\circ} \mathrm{C}\right)$ in the annual observations of temperature change, and steps of $\pm 10 \%$ from the minimum to the maximum change in annual precipitation $(-30 \%$ to $+30 \%$ ). However, where projected CC did not span this full range of changes in temperature and rainfall, the range with reduced to capture the projected range plus the neighbouring range. Thus, for the example in Fig. 1a this means that the range was set to 1 to $7^{\circ} \mathrm{C}$ change in temperature and -20 to $30 \%$ change in precipitation.

For method A, the daily observed temperature and precipitation were changed by the same value all year round. This is similar to the $\Delta$-change method by Olesen et al. (2007).

For method B, the meteorological data were changed using seasonal projected changes in precipitation and temperature. As the seasonal changes cannot be represented by two dimensions as for method A (annual temperature change, annual change in precipitation), but have four seasonal temperature changes (DJF, MAM, JJA, SON) and four seasonal changes in precipitation (DJF, MAM, JJA, SON), the total number of dimensions will be 16 . Simplifications of the projected CC were introduced to reduce the number of combinations to 2 dimensions. The seasonal projections were normalised into the same number of combinations as for method A, but instead of using annual changes, mean seasonal changes in temperature and precipitation were added to the daily meteorological data. This was done by: (1) classifying the $\mathrm{CC}$ data according to the mean annual change in temperature and precipitation using the same steps as for method $\mathrm{A}$ of $+1{ }^{\circ} \mathrm{C}$ and $\pm 10 \%$ precipitation; and (2) 


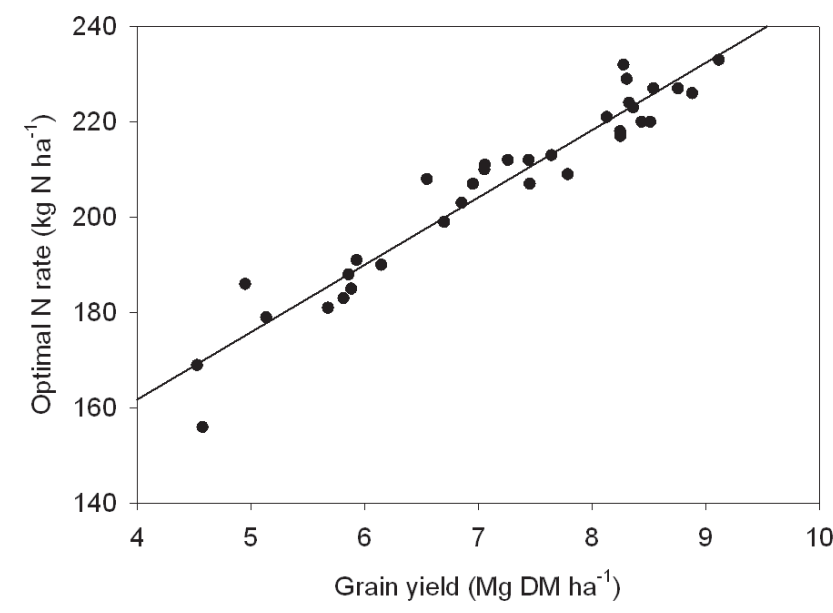

Fig. 2. Regression between the optimal $\mathrm{N}$ fertilizer rate and grain yield of winter wheat at the optimal $\mathrm{N}$ rate. Based on simulated data of Olesen et al. (2007).

calculating mean seasonal change in temperature and precipitation for each of the 42 combinations. To illustrate, mean seasonal changes in precipitation were calculated from the seasonal observations underlying each of the annual observations within each of the grids in Fig. 1a. The mean seasonal changes were used to change temperature and precipitation in the meteorological datasets.

Table 1 shows mean annual and seasonal temperatures and precipitation for all projection periods. Before using the data as input in the Daisy model, the precipitation was corrected to apply to the soil surface with a mean $+10 \%$ correction applied throughout the year according to Allerup et al. (1998). The correction was found by comparing standard meteorological measurements of precipitation at $1.5 \mathrm{~m}$ height with measurement at the soil surface, and is primarily caused by turbulence effects around the measurement rain gauge at $1.5 \mathrm{~m}$ height.

The projected $\mathrm{CO}_{2}$ concentrations for the A1B scenario were taken from Houghton et al. (2001) as the ISAM model results. This impacts the modelled photosynthesis rate, transpiration and critical $\mathrm{N}$ concentrations in the vegetative parts of the plant. A detailed description of how the Daisy model parameters were modified, is given in Appendix A.

The first six years of the meteorological data were used as an initialisation period for the Daisy simulations of soil water and organic matter contents and the last $24 \mathrm{yr}$ as the result period. Projections of $\mathrm{CC}$ included only changes in precipitation and temperature. Global radiation, wind speed and humidity were kept unchanged as these parameters are generally less affected by $\mathrm{CC}$ and because they mostly have little impact on crop yield and $\mathrm{N}$ leaching.

We are aware that the baseline time series (1961-1990) from which climate change was calculated (Harris et al., 2010) is different from the MARS-STAT series (1975-2005),
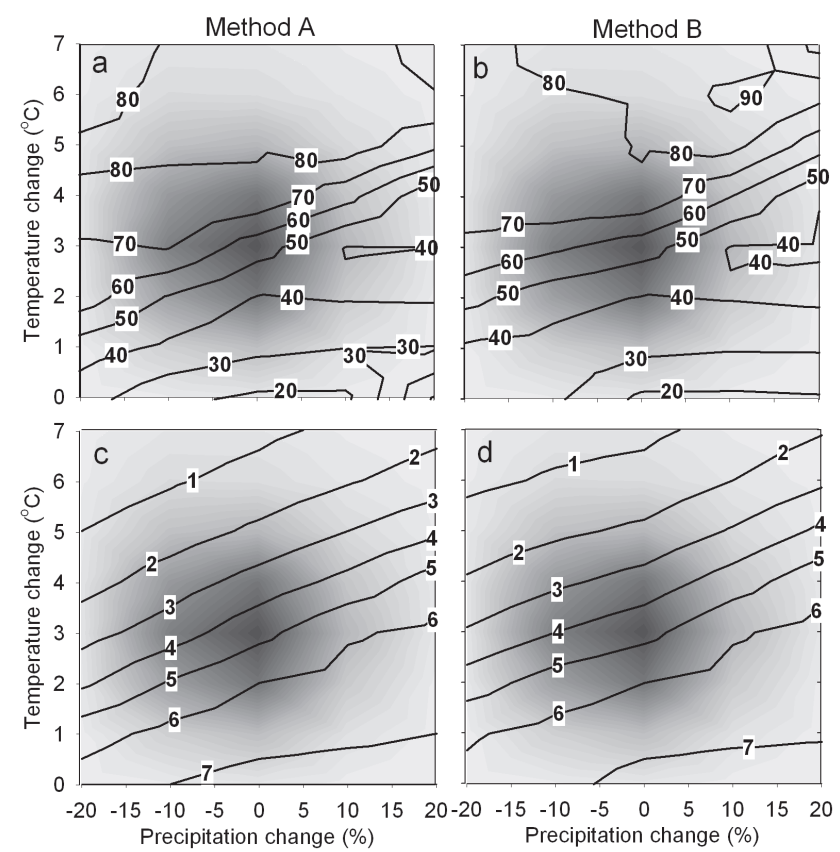

Fig. 3. Mean simulated $\mathrm{N}$ leaching $\left(\mathrm{kg} \mathrm{N} \mathrm{ha}^{-1}\right)$ (a and b) and grain yield (Mg DM ha $\left.{ }^{-1}\right)$ of winter wheat (c and $\left.\mathbf{d}\right)$ as contour lines for loamy sand in Denmark for changes in temperature and precipitation using method A (a and $\mathbf{c}$ ) and method B (b, d). The background shading shows the probability (\%) of changes in air temperature and precipitation during 2061-2080 for Denmark compared to the baseline period 1961-1990. The simulations used the $\mathrm{CO}_{2}$ concentration for 2070 (611 ppm). The legend for the shading is shown in Fig. 1.

but we assume that this has only a minor influence on the trends in the simulations compared to other uncertainties. An equally important issue is that the method of $\mathrm{CC}$ projections applied here does not account for changes in frequency and duration of droughts and intense precipitation events.

\subsection{Crop management and soil types}

Model simulations were run for continuous winter wheat on two typical Danish soil types: Sand (S) (4\% clay and 2.2\% organic matter in the topsoil, $60 \mathrm{~mm}$ root zone water holding capacity, RZWC) and loamy sand (LS) (12\% clay and $2.3 \%$ organic matter in the topsoil, $245 \mathrm{~mm}$ RZWC). The soils were assumed to be free draining and, thus, not affected by high ground water table, nor were they irrigated. The two soil types were used to illustrate potential soil typedependent differences in grain yield and $\mathrm{N}$ leaching response to change in climatic conditions.

For each combination of soil type ( $\mathrm{S}$ and LS), meteorological datasets (42) and CC projection methodology (A and $\mathrm{B}$ ), the optimum $\mathrm{N}$ fertilization rate was initially calculated. A regression function describing the relation between soil- and climate-potential yield and optimum $\mathrm{N}$ rate (Fig. 2) 
was used to calculate the optimum $\mathrm{N}$ rate. The regression was found from simulations with five soil types, nine European climates, and five $\mathrm{N}$ rates $(50,100,150,200$, and $250 \mathrm{~kg} \mathrm{Nha}^{-1}$ ) (Olesen et al., 2007). The maximum grain yield was initially simulated at a high $\mathrm{N}$ rate (no simulated $\mathrm{N}$ stress on crop yield) and subsequently the economical optimum $\mathrm{N}$ rate was calculated. Adjusting the $\mathrm{N}$ application rate to track changes in grain yield due to changed climatic conditions is an important assumption on adaptation to climate change that also affects the response of the simulated $\mathrm{N}$ leaching under future climatic conditions.

Common farm management practice in relation to timing of sowing and fertilization was used in the simulations. To adopt the effect of increased temperature on management, the date of sowing was delayed by five days for every $1{ }^{\circ} \mathrm{C}$ of temperature increase (Olesen et al., 2000). This is to guard against too advanced crop development during autumn, which may lead to susceptibility to winter frost damage. Harvest day was simulated when maturation was reached in the simulations.

\subsection{Effects of climate change}

Examples of simulated grain yield and $\mathrm{N}$ leaching combined with the PDFs of CC are presented in Fig. 3. A straightforward method to obtain the most likely response would be to simulate the response from the mean value of CC projection (e.g., approximately no change in precipitation and $+3{ }^{\circ} \mathrm{C}$ warming for 2061-2080, Fig. 3). The validity of this method is based on an assumed linear response of grain yield and $\mathrm{N}$ leaching to changes in temperature and precipitation, which would be seen in Fig. 3 as parallel and equidistant contour lines of grain yield and $\mathrm{N}$ leaching within the response surface. The simulated responses are clearly not linear. We, therefore, used an alternative method for deriving the most likely effects of $\mathrm{CC}$ on yield and $\mathrm{N}$ leaching by calculating a probability weighted effect of the different $\mathrm{CC}$ projections. This is done by calculating the stochastic probability of climate change for each of the grid cells (Fig. 3), multiplying it by the simulated value obtained for that grid cell and then adding the results over the entire probability space.

Two types of simulation results are obtained: (1) average results ( $\left.A_{\text {yield, }}, A_{\text {leaching }}\right)$ and (2) probability for exceeding a threshold value $\left(P_{\text {yield }}, P_{\text {leaching }}\right)$. The average results give information on the long-term mean effects, whereas the probability of exceeding threshold values gives estimates on frequencies of extremes (years with high $\mathrm{N}$ leaching or years with low grain yields). Threshold values of $20 \%$ reduction in annual grain yield compared to baseline and the probability of exceeding a threshold of soil specific $\mathrm{N}$ leaching level larger than $50 \mathrm{~kg} \mathrm{Nha}^{-1}$ (LS) and $70 \mathrm{~kg} \mathrm{Nha}^{-1}$ (S) were calculated. These values correspond to current levels of nitrate leaching from winter cereal cropping in Denmark. The average measured $\mathrm{N}$ leaching from a wide range of experiments in winter cereals mostly fertilized with mineral fertilizer in Denmark showed an average annual $\mathrm{N}$ leaching of $52 \mathrm{~kg} \mathrm{Nha}^{-1}$ (Kristensen et al., 2008). Kronvang et al. (2009) studied the $\mathrm{N}$ leaching from different catchments in Denmark and found average annual $\mathrm{N}$ leaching from the root zone of $78 \mathrm{~kg} \mathrm{Nha}^{-1}$ for sandy soils and $47 \mathrm{~kg} \mathrm{Nha}^{-1}$ for loamy soils. The thresholds chosen, therefore, represents high $\mathrm{N}$ leaching rates that should not be exceeded.

The projected probability of $\mathrm{N}$ leaching exceeding a certain threshold $\left(P_{\text {leaching }}\right)$ is calculated as:

$P_{\text {leaching }}=\sum_{T=0^{\circ} C}^{+7^{\circ} \mathrm{C}} \sum_{P=-30 \%}^{+30 \%} P_{\mathrm{clm}} \cdot P_{\mathrm{clm}}$, leaching

where $P_{\mathrm{clm}}$ is the probability calculated for a given CC projection and $P_{\text {clm, leaching }}$ is the probability of $\mathrm{N}$ leaching exceeding the soil specific threshold value at the given CC. The projected probability of a grain yield reduction larger than $20 \%$ compared to baseline is calculated in a similar way:

$P_{\text {yield }}=\sum_{T=0^{\circ} C}^{+7^{\circ} C} \sum_{P=-30 \%}^{+30 \%} P_{\text {clm }} \cdot P_{\text {clm, yield }}$

where $P_{\text {clm, yield }}$ is the probability of a yield reduction of $>20 \%$ compared to the average yield baseline. Average grain yields are calculated using a similar equation substituting $P_{\text {clm, yield }}$ in Eq. (2) with $A_{\text {clm, yield (average simulated }}$ grain yield) and average $\mathrm{N}$ leaching is found by substituting $P_{\text {clm, Leaching }}$ in Eq. (1) with $A_{\text {clm, Leaching }}$ (average simulated N leaching).

Equations (1) and (2) estimate the probability of exceeding thresholds for individual years. However, it is also of interest to know if projected average grain yield and $\mathrm{N}$ leaching exceed the above-mentioned thresholds. In this case, the probability of average $\mathrm{N}$ leaching exceeding a specified threshold was calculated as:

$P_{\text {leaching }}=\sum_{T=0^{\circ} \mathrm{C}}^{+7^{\circ} \mathrm{C}} \sum_{P=-30 \%}^{+30 \%} P_{\mathrm{clm}} \cdot \alpha\left(A_{\mathrm{clm}, \text { leaching }}, A_{\text {thres, leaching }}\right)$

$\alpha\left(A_{\text {clm, leaching }}, A_{\text {thres,leaching }}\right)=\left\{\begin{array}{l}1 \text { for } \mathrm{A}_{\mathrm{clm}, \text { leaching }}>\mathrm{A}_{\text {thres, leaching }} \\ 0 \text { otherwise }\end{array}\right.$

where $A_{\mathrm{clm}}$, leaching is the average simulated $\mathrm{N}$ leaching for the specified climate and $A_{\text {thres, leaching }}$ is the leaching threshold, which was set to $50 \mathrm{~kg} \mathrm{Nha}^{-1}$ for LS soil and $70 \mathrm{~kg} \mathrm{Nha}^{-1}$ for S soil.

The probability for average grain yield being lower than the specified thresholds of $20 \%$ less than the mean grain yield under baseline conditions was calculated in a similar way. 
Table 1. Mean seasonal and annual precipitation $\left(\mathrm{mm} \mathrm{y}^{-1}\right)$ corrected to soil surface and mean air temperature $\left({ }^{\circ} \mathrm{C}\right)$ of the baseline period (1961-1990, which was scaled to the observation period 1982-2005) and the projected climate scenarios obtained for all periods for the study area in Denmark. The change shows the difference between 2081-2100 and 1961-1990.

\begin{tabular}{|c|c|c|c|c|c|c|c|c|c|c|}
\hline \multirow[b]{2}{*}{ Years } & \multicolumn{5}{|c|}{ Precipitation (mm) } & \multicolumn{5}{|c|}{ Mean temperature $\left({ }^{\circ} \mathrm{C}\right)$} \\
\hline & DJF & MAM & JJA & SON & Annual & DJF & MAM & JJA & SON & Annual \\
\hline 1961-1990 & 148 & 133 & 193 & 205 & 679 & 1.2 & 6.4 & 15.5 & 9.4 & 8.2 \\
\hline 2001-2020 & 153 & 136 & 184 & 208 & 682 & 2.3 & 7.5 & 16.9 & 10.6 & 9.4 \\
\hline 2011-2030 & 156 & 139 & 187 & 211 & 693 & 2.8 & 7.8 & 17.2 & 10.9 & 9.7 \\
\hline 2021-2040 & 159 & 141 & 187 & 214 & 701 & 3.1 & 8.0 & 17.5 & 11.3 & 10.0 \\
\hline $2031-2050$ & 159 & 141 & 188 & 214 & 702 & 3.4 & 8.3 & 18.0 & 11.8 & 10.4 \\
\hline $2041-2060$ & 159 & 141 & 188 & 214 & 703 & 3.9 & 8.7 & 18.5 & 12.3 & 10.8 \\
\hline $2051-2070$ & 161 & 142 & 185 & 216 & 704 & 4.5 & 9.2 & 18.9 & 12.7 & 11.3 \\
\hline $2061-2080$ & 161 & 142 & 184 & 215 & 702 & 4.7 & 9.4 & 19.3 & 13.1 & 11.6 \\
\hline 2071-2090 & 160 & 142 & 184 & 215 & 700 & 4.9 & 9.7 & 19.9 & 13.4 & 11.9 \\
\hline 2081-2100 & 160 & 141 & 183 & 215 & 699 & 5.3 & 9.9 & 20.4 & 13.8 & 12.3 \\
\hline Change & 12 & 8 & -10 & 10 & 20 & 4.13 .5 & 4.9 & 4.4 & 4.2 & \\
\hline
\end{tabular}

\section{Results}

\subsection{Projected climate change}

These projected seasonal changes in precipitation differed considerably from annual changes (Table 1). There were generally only moderate changes in projected annual precipitation with an increase of $20 \mathrm{~mm} \mathrm{y}^{-1}$ by 2100 , which, for method A, means that the annual precipitation increases by $3 \%$ compared with baseline (1961-1990). For the seasonal precipitation in the periods DJF, MAM, JJA and SON the increases were $12,8,-10$ and $10 \mathrm{~mm} \mathrm{y}^{-1}$, respectively. Generally, the temperature rises at nearly the same rate for all four seasons, although there is a tendency for the largest increases to occur in the summer period (JJA) and the smallest in spring (MAM). The annual mean temperature increased by $4.2^{\circ} \mathrm{C}$ during the analysed period. Temperature increased approximately linearly during the whole period. Table 1 only presents the projected mean changes in temperature and precipitation, whereas the results of Harris et al. (2010) used here also included the uncertainties in the projections, and this uncertainty further increased future projections. It should be noted that 1961-1990 was used as the baseline period in the climate projections in Harris et al. (2010), but observed data from 1982-2005 was used as the baseline period for the crop simulations.

\subsection{Effects on grain yield}

Mean wheat grain yields and $\mathrm{N}$ leaching were simulated for a range of combinations of temperature and precipitation changes using methods A and B (see Sect. 2.2). The joint response of temperature and precipitation changes (including the change of atmospheric $\mathrm{CO}_{2}$ concentration) on grain yields and $\mathrm{N}$ leaching is illustrated as contour lines in Fig. 3 for winter wheat grown on the LS soil type. The results of using methods A and B in simulation of grain yields are shown in Fig. 3c, d, respectively. For both methods, grain yield decreased with increasing temperature and decreasing precipitation. Generally, the decrease in yield was slightly larger for method A than method B. The distance between contour lines indicates the sensitivity at a certain range of changes in annual temperature and precipitation. For both methods the reduction in yields was larger for temperature increases between +2 to $+4{ }^{\circ} \mathrm{C}$ than for increases from 0 to $+2{ }^{\circ} \mathrm{C}$.

Overlaid on the contour lines in Fig. 3 is the joint PDF for CC (2061-2080) calculated in a similar way to that shown in Fig. 1. Figure $4 \mathrm{a}$ shows mean yields and the standard deviation obtained for the two soil types, S and LS, and the two methods A and B. The mean wheat yields were obtained by combining the simulation results (results presented as contour lines in Fig. 3) with the PDF using Eq. (2). The standard deviation of the yields was calculated from a generated sample of 10000 simulation results taken as the mean simulated results for each of the 42 combinations of the climate space replicated a number of times corresponding to the PDF-weight of the respective grid in Fig. 1a. This standard deviation is an approximation that does not include the variability within years and within each grid. Differences in mean yield due to methodology are relatively small compared to the uncertainty associated with the CC projections (standard deviation shown with error bars in Fig. 4a). There are large differences in simulated grain yield between soil types, with the highest yields on the LS soil. The absolute yield decrease during the period was simulated to be largest for the LS soil, in particular during the latter part of the period (2030 to 2090).

The probability of yield reductions in individual years larger than $20 \%$ compared to mean yields under baseline 


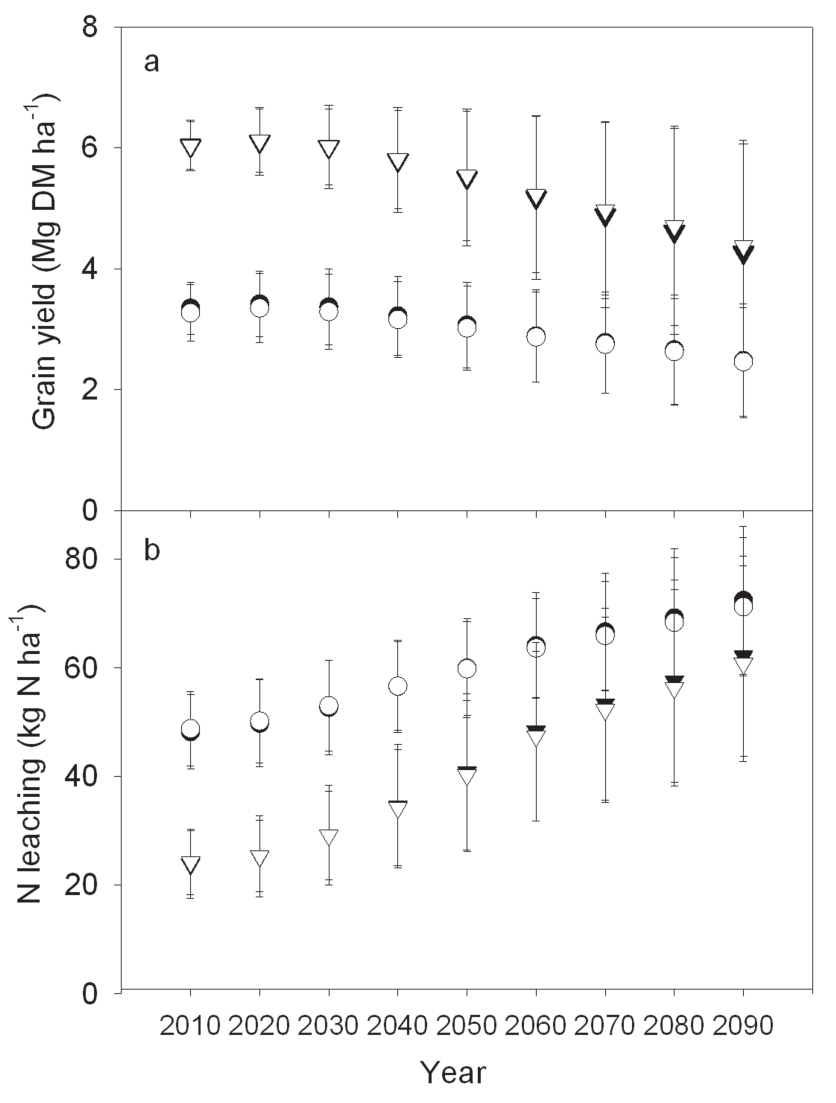

Fig. 4. Mean winter wheat grain yield (a) and $\mathrm{N}$ leaching (b) under projected climate for two soil types (sand S and loamy sand LS). Results are shown for methods $\mathbf{A}$ and $\mathbf{B}$. The error bars show the standard deviation.

conditions ( $\left.P_{\text {yield }}\right)$ was calculated using Eq. (2) and is shown in Fig. 5a. The simulated grain yields under baseline climate and $\mathrm{CO}_{2}$ concentrations $(353 \mathrm{ppm})$ were 3.7 and 6.1 $\mathrm{Mg} \mathrm{DM} \mathrm{ha}^{-1}$ for S and LS soils, respectively, and the corresponding simulated grain yields for 2010 were 3.3 and $6.0 \mathrm{Mg} \mathrm{DM} \mathrm{ha}{ }^{-1}$. The change in probability of low yields is related to changes in mean yields (Fig. 4a). A general reduction in average yields increases the probability of yield reductions larger than $20 \%$. There is a small increase in probability of low yields for $\mathrm{S}$ soil and a larger increase for LS soil. The minor increase for $\mathrm{S}$ is due to the lower root zone capacity of this soil type making the crop growth on $\mathrm{S}$ soils more sensitive to periods with low precipitation during the growing season already under current climate. For LS the larger root zone capacity leads to projections of low probabilities of low yields for the decades up to 2040, but increasing probabilities in the later decades associated with lower mean yields and the increased uncertainty in projected grain yield, which increases the risk of low yields (Fig. 4a).

Figure 6a shows the probabilities of average yields being lower than the threshold of $20 \%$ less than the average of baseline yields. There is a considerably larger change in

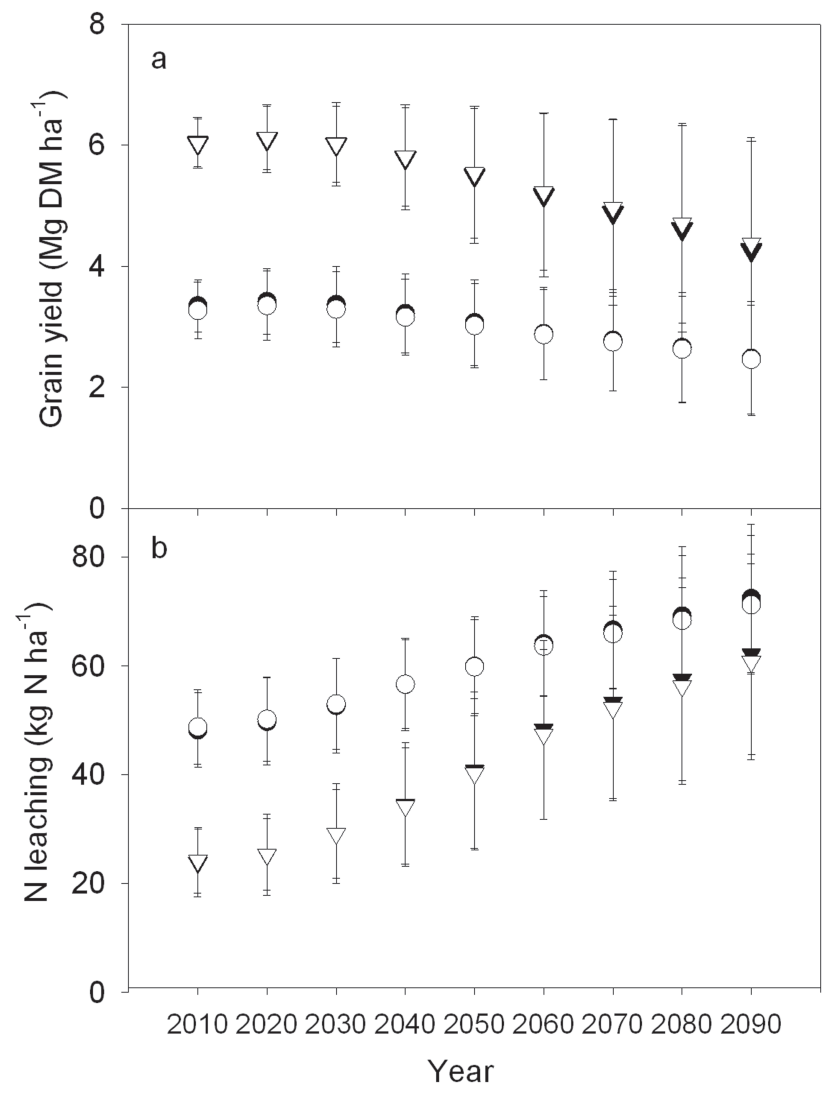

Fig. 5. Probability of yield reductions in individual years larger than $20 \%$ compared to mean yield simulated for baseline and probability of $\mathrm{N}$ leaching in individual years exceeding threshold levels of $50 \mathrm{~kg} \mathrm{Nha}^{-1}$ for loamy sand and $70 \mathrm{~kg} \mathrm{Nha}^{-1}$ for sandy soils. Results were calculated for projected climate conditions at 10-yr intervals during the 21 st century for the $\mathrm{A} 1 \mathrm{~B}$ emission scenario using the two methodologies A and B.

probability of changes in mean yields than in probabilities of low yields for individual years (compare Figs. 5a and 6a). The probability of low average yields increased almost linearly over time for the LS soil from about 0 in 2010 to about $50 \%$ in 2080 . For probability of low average yields for the $\mathrm{S}$ soil increased at a similar rate from about $20 \%$ in 2010 to about $60 \%$ in 2050 , and remained at this high level for the rest of the period. The apparent drop in probability from 2050 to 2060 is mostly an artefact of the division into grid cells (see Fig. 1a). It would probably not have been there if a finer grid of temperature and precipitation changes had been used for calculating the response surface.

\subsection{Effects on nitrate leaching}

Simulated $\mathrm{N}$ leaching is affected more by temperature than precipitation changes within the range investigated (Fig. 3a, b). Increased precipitation leads to a small reduction in $\mathrm{N}$ leaching at current temperature, but to larger leaching at 


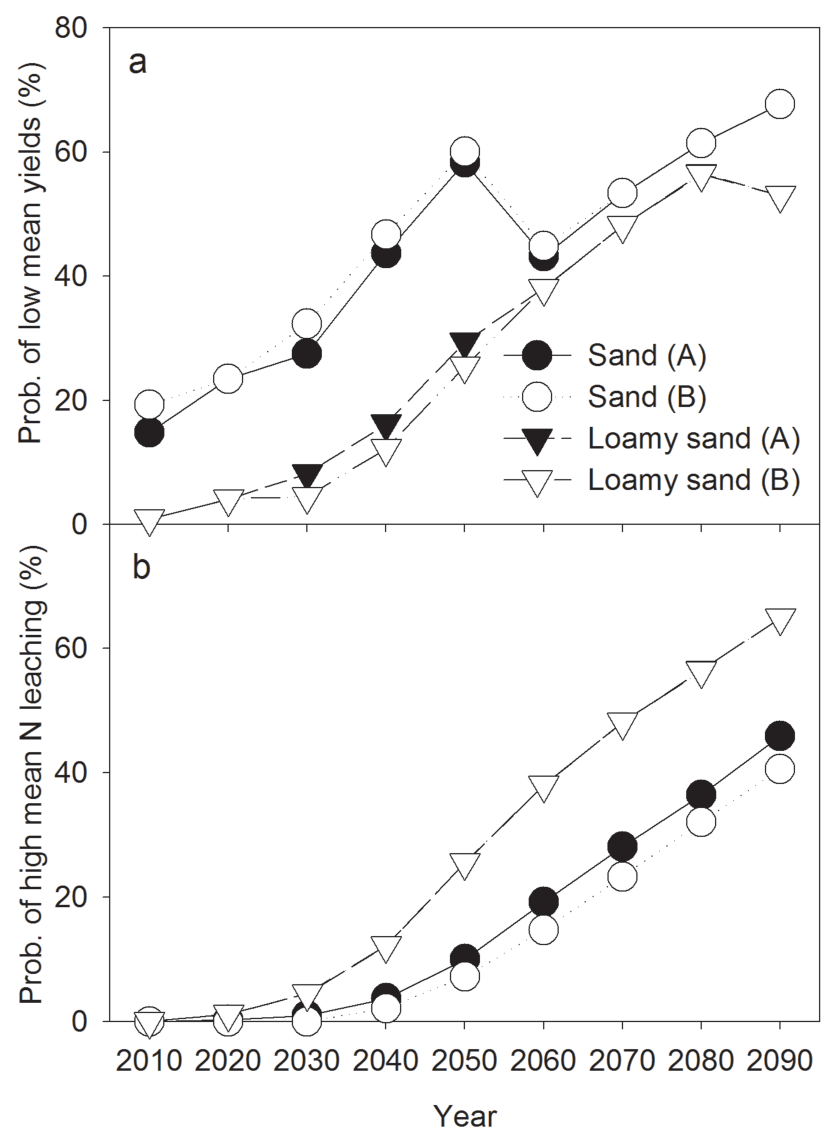

Fig. 6. Probability of mean yield reduction larger than $20 \%$ compared to yield simulated for baseline and probability of mean $\mathrm{N}$ leaching exceeding threshold levels of $50 \mathrm{~kg} \mathrm{~N}^{-1}$ for loamy sand and $70 \mathrm{~kg} \mathrm{~N} \mathrm{ha}^{-1}$ for sandy soils. Results were calculated for projected climate conditions at $10-\mathrm{yr}$ intervals during the 21 st century for the A1B emission scenario using methodologies A and B.

higher temperatures. Increased temperature leads to higher $\mathrm{N}$ leaching, in particular, for temperature increases above $+3{ }^{\circ} \mathrm{C}$.

$\mathrm{N}$ leaching is generally largest for $\mathrm{S}$ soils due to the low root zone capacity (Fig. 4b). The uncertainty in $\mathrm{N}$ leaching associated with $\mathrm{CC}$ projections is generally highest for the LS soil. There is little difference in mean $\mathrm{N}$ leaching between the methods for both soil types.

The probability ( $P_{\text {leaching }}$ ) of nitrate leaching exceeding soil specific $\mathrm{N}$ leaching levels $\left(70 \mathrm{~kg} \mathrm{Nha}^{-1}\right.$ for $\mathrm{S}$ and $50 \mathrm{~kg} \mathrm{Nha}^{-1}$ for LS) for individual years was calculated from Eq. (1) (Fig. 5b). The threshold leaching levels should be compared with simulated mean $\mathrm{N}$ leaching under baseline conditions of 41 and $21 \mathrm{~kg} \mathrm{Nha}^{-1}$ for S and LS soils, respectively. The trends over time show a small increase in probability for high $\mathrm{N}$ leaching levels for $\mathrm{S}$ soils and a considerably larger change for LS soils. There is little change in probability of high $\mathrm{N}$ leaching of $\mathrm{S}$ soils, despite a considerable increase in mean $\mathrm{N}$ leaching over the projection period, but this is also coupled to an increase in projection uncertainty, which in this case reduces the probability of high $\mathrm{N}$ leaching events.

The probability of average $\mathrm{N}$ leaching exceeding the threshold increases considerably from almost zero in 2020 to about $60-70 \%$ by 2050 for LS soil (Fig. 6b), whereas the increase is smaller for S soil, though by 2090 the probability of mean $\mathrm{N}$ leaching above the soil specific thresholds is above $40 \%$ for both soil types. The effect of the method of application of the $\mathrm{CC}$ projections ( $\mathrm{A}$ or $\mathrm{B}$ ) varies between the two soil types with the highest probability for method A for the $\mathrm{S}$ soil and no difference between methods for the LS soil.

\section{4 $\quad \mathrm{N}$ fertilization and $\mathbf{N}$ use efficiency}

The $\mathrm{N}$ fertilizer rate is directly related to expected yields using the empirical relation in Fig. 2. The changes in $\mathrm{N}$ fertilization rates (Fig. 7a) generally follows the changes in grain yield over time (Fig. 4a). The $\mathrm{N}$ rate decreases for both soils due to a decrease in yields during the analysed period, and there is little difference in response for the two methods.

The $\mathrm{N}$ use efficiency was calculated as the harvested $\mathrm{N}$ in grain divided by the applied fertilizer $\mathrm{N}$ rate. The soil type has a large effect on $\mathrm{N}$ use efficiency with $\mathrm{N}$ use efficiencies generally less than $60 \%$ on $\mathrm{S}$ soil, whereas $\mathrm{N}$ use efficiency is mostly above $80 \%$ for LS soil. There is a reduction in $\mathrm{N}$ use efficiency over time for both soil types, but again LS is most affected.

\section{Discussion}

\subsection{Grain yield responses}

Temperature and precipitation both greatly influence modelled grain yield in winter wheat (Wolf et al., 1996). Increasing temperatures reduce yield by shortening crop growth duration and, thus, the period of active growth (Challinor et al., 2004; Kristensen et al., 2011). Higher temperatures during grain-filling will lead to particularly large yield reductions. Precipitation and temperature also affect the amount of soil water available for transpiration. The effect of changes in precipitation and evapotranspiration is assumed to be larger on soils with a low root zone water-holding capacity (i.e., higher response on shallow sandy soils compared with deeper loamy sand soils). However, the simulations show that absolute yield reductions under CC are larger for LS compared with the S soils (Fig. $4 \mathrm{a}$ ). This is a consequence of larger yields on the LS soil and similar projected relative yield decreases (about $30 \%$ ) for the two soil types for the entire projection period.

The simulations with the Daisy model show a nonlinear response to temperature change that also depends on precipitation (Fig. 3). Under baseline climatic conditions in Northern Europe (Denmark), the simulations show very little response of grain yield to changing temperature (changes of 


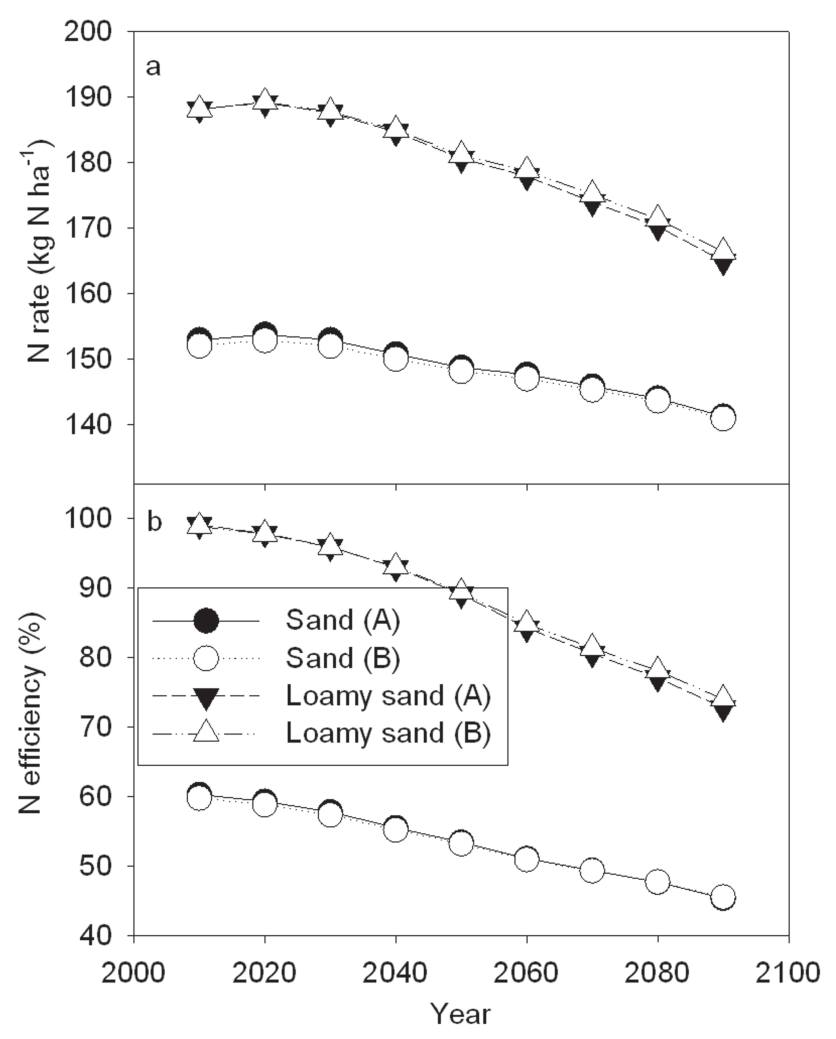

Fig. 7. $\mathrm{N}$ fertilization rate optimized to the annual mean yields and the $\mathrm{N}$ use efficiency ( $\mathrm{N}$ in grain harvested divided by $\mathrm{N}$ fertilization rate). Results were calculated for projected climate conditions at 10 -yr intervals during the 21 st century for the A1B emission scenario using methodologies $\mathrm{A}$ and $\mathrm{B}$.

up to $+1^{\circ} \mathrm{C}$ ). This is largely in line with empirical observations in Denmark showing yield reductions of about 3-4\% for each $1{ }^{\circ} \mathrm{C}$ temperature increase, but with increased yield reductions at higher temperatures (Kristensen et al., 2011).

The yield reductions, caused by higher temperatures, are to some extent offset by the increased $\mathrm{CO}_{2}$ concentration that enhances photosynthesis and lowers transpiration. Because the effect of elevated $\mathrm{CO}_{2}$ concentration shows a nonlinear response with declining effects at higher concentrations (Olesen and Bindi, 2002), the yield benefits of enhanced $\mathrm{CO}_{2}$ are more pronounced in the near term than towards the end of the projection period.

The lack of a full compensatory effect of $\mathrm{CO}_{2}$ can also be partly attributed to the method of estimating the yield changes in Fig. 4. These are based on a weighted average of results from the full uncertainty range of CC projections. Since there is a nonlinear response of grain yield to $\mathrm{CC}$ resulting in considerably higher yield losses at increasingly large CCs (increased temperature and lower summer precipitation), which results in overall lower grain yields compared to simulated grain yield changes at the median changes in temperature and precipitation.
The projected effects on yield and $\mathrm{N}$ leaching shown here only reflect changes in mean temperature and rainfall. If changes in inter-annual variability of temperature and precipitation had also been included, this might have led to increased risk of low yields (Wolf et al., 1996).

\subsection{N leaching responses}

Simulated nitrate leaching was higher for sandy soils at $59 \mathrm{~kg} \mathrm{~N} \mathrm{ha}^{-1}$ (average over the entire projection period) compared with $41 \mathrm{~kg} \mathrm{~N} \mathrm{ha}^{-1}$ for sandy loamy soils (Fig. 4b). The difference between the two soil types agrees with measured data from Danish field experiments (Simmelsgaard, 1998).

Several factors related to $\mathrm{CC}$ affect $\mathrm{N}$ cycling and, thus, $\mathrm{N}$ leaching in agroecosystems. Higher $\mathrm{CO}_{2}$ concentrations lead to higher $\mathrm{CO}_{2}$ assimilation with concomitant increases in plant $\mathrm{C} / \mathrm{N}$ ratios (Soussana and Lüscher, 2007), higher rhizodeposition (release of dead organic substrates from the roots to the soil) (Bazot et al., 2008) and reduced crop transpiration (Kruijt et al., 2008), which influences plant N uptake and soil $\mathrm{C}$ and $\mathrm{N}$ dynamics (Sowerby et al., 2005). In many environments this leads to more N-efficient crops, which reduces the risk of $\mathrm{N}$ leaching. However, under Danish climatic conditions $\mathrm{N}$ efficiency for winter wheat is projected to decline over time due to lower yields and especially to increased $\mathrm{N}$ leaching levels.

Higher temperatures and elevated $\mathrm{CO}_{2}$ will also entail changes in planting and harvesting times as well as in fertilization rates and strategies (Olesen et al., 2007, 2011). In the current simulations it is assumed that winter wheat would be sown later and that fertilization rates would follow the expected yield level. This resulted in reduced $\mathrm{N}$ fertilizer rates over time, in particular, for the loamy sand soils. An earlier harvest and later planting of winter wheat may result in a prolonged period of bare soil in autumn, which will increase the risk of N loss (Olesen et al., 2004), particularly in connection with increased autumn and winter precipitation in temperate regions (Eckersten et al., 2001).

There was a strong nonlinear response of $\mathrm{N}$ leaching to changes in precipitation and temperature (Fig. 3a, b). For method A with similar changes in precipitation this results mostly in reduced $\mathrm{N}$ leaching at higher precipitation (Fig. 3a), primarily because reductions in summer precipitation can cause crop failure and low $\mathrm{N}$ uptake that increases risk of $\mathrm{N}$ leaching. The same was seen for method $\mathrm{B}$, even though this produced larger increases in winter than in summer precipitation. Increased $\mathrm{N}$ leaching was simulated only at high precipitation. This effect only showed up as increased $\mathrm{N}$ leaching at high precipitation for large increases in temperature. However, in total, there is little difference between the two methods in projected mean $\mathrm{N}$ leaching and probability of exceeding the leaching thresholds.

Warming is expected to increase soil organic matter turnover provided sufficient water is available, and experiments have shown that increases in net $\mathrm{N}$ mineralisation rates 
may be considerably higher than the increases in soil respiration (Rustad et al., 2001). A longer period in autumn with bare soil under a warmer climate (Olesen et al., 2004) - in combination with increased soil organic matter turnover due to higher temperatures (Turner and Henry, 2010) - may increase the risk of $\mathrm{N}$ loss, in particular through $\mathrm{N}$ leaching. This is probably the main reason for the increased risk of $\mathrm{N}$ leaching at higher temperatures (Fig. 3a, b).

The projected increase in nitrate leaching with higher temperatures is in line with an independent simulation study by Patil et al. (2011) that showed increasing $\mathrm{N}$ leaching from winter wheat in Denmark with increasing temperature, in particular, for a sandy loam soil at temperature increases of above $2{ }^{\circ} \mathrm{C}$. They also found higher simulated soil mineral $\mathrm{N}$ concentrations at crop harvest and, thus, higher risk of $\mathrm{N}$ leaching during winter, which was ascribed to less $\mathrm{N}$ uptake by the crop and increased $\mathrm{N}$ mineralisation from soil organic matter.

The increasing uncertainty in CC projections with longer projection times is probably the reason why the probability of high $\mathrm{N}$ leaching does not increase for $\mathrm{S}$ soils towards the end of the century, even though the weighted mean $\mathrm{N}$ leaching increases (Figs. 4, 5).

\subsection{Sources of uncertainty}

The methodology for applying CC projections had little effect on projections of both grain yield and $\mathrm{N}$ leaching and this effect can, therefore, be largely ignored. The reason for the small response to method for constructing the response surfaces was probably that the model responded mostly to changes in temperature and less so to changes in precipitation, and the seasonal changes in climate change projections were greater for precipitation than for temperature (Table 1).

The projections of probabilities of low yields or high $\mathrm{N}$ leaching showed little response over time for $\mathrm{S}$ soil where individual years was concerned (Fig. 5), whereas there was a considerable increase over time in the probability of mean values of grain yield and $\mathrm{N}$ leaching exceeding the thresholds (Fig. 6). For the LS soil, the probability of exceeding the threshold increased considerably more over time for the mean values of both grain yield and $\mathrm{N}$ leaching than for the assessment of individual years. These differences between responses of probabilities for individual years and for average responses reflect changes in both average grain yield and $\mathrm{N}$ leaching and in the uncertainty of their predictions. A more uncertain prediction will tend to reduce the probability for exceedance for individual years, but to increase it for the average response.

The uncertainty in CC projections was found to be the dominating source of uncertainty for the projections of grain yield. The uncertainty of $\mathrm{CC}$ projections on grain yield and $\mathrm{N}$ leaching was generally highest for LS soil. The larger uncertainty in projected yield for LS is most likely caused by the higher yield level. Because the uncertainty in projected temperature and precipitation increases over time, there is also an increase in the uncertainty of simulated yield and $\mathrm{N}$ leaching during the projection period (Fig. 4).

The methodology had little effect on average projected grain yield or $\mathrm{N}$ leaching (Fig. 4) for both soil types. The only effect was found for the probability of high mean $\mathrm{N}$ leaching for S soil (Fig. 6b). Neither of the two methods of applying climate projections considered changes in frequency of dry and wet periods, which may affect both $\mathrm{N}$ leaching and crop yield, although the response is likely to be small (Patil et al., 2010). As for the observed effects of changes in mean precipitation, any changes in precipitation intensity and duration of dry periods would be expected to be most severe for the sandy loam soils. It would be expected that using seasonally corrected CC should give the most reliable projections of changes in grain yield and $\mathrm{N}$ leaching. However, the effect seems to be small compared to the uncertainty associated with $\mathrm{CC}$ projections.

An additional uncertainty related to the methodology concerns the use of a grid of fixed changes at regular intervals of temperature and precipitation (Fig. 1a). The resolution of this grid (i.e., the spacing of the intervals) will affect the estimated mean yield, their variability and also the estimated probabilities of exceedance of thresholds. The effect of grid resolution was not assessed in this study. However, it is likely that at least some of the variation over time in estimated probability of low mean yield for the $\mathrm{S}$ soil is associated with the grid resolution (Fig. 6a). The grid resolution should reflect the main sensitivity of the model in response to the environmental variables. In our case, it would mean that a higher grid resolution is required for temperature than for rainfall (Fig. 3). It would probably have been advisable to have used a grid resolution of $0.5^{\circ} \mathrm{C}$ instead of the $1^{\circ} \mathrm{C}$ that was actually applied.

Two typical Danish soil types were chosen to represent soil type effects on crop yields and $\mathrm{N}$ leaching under CC. The organic matter content is relatively high for soils in Denmark compared to arable soils in warmer regions of Europe. Since soil organic matter influences the $\mathrm{N}$ cycling through the contribution of mineralisation of organic $\mathrm{N}$, the high mineralisation rates under warmer climates may partly explain the relatively high $\mathrm{N}$ use efficiencies and relatively high $\mathrm{N}$ leaching levels obtained in this study (Fig. $7 \mathrm{~b}$ and Fig. 4b, respectively).

\section{Conclusions}

A new method for obtaining probabilistic $\mathrm{CC}$ projections of $\mathrm{N}$ leaching and grain yield due to climate change was applied for winter wheat in Denmark. The method involves simulating the response of crop growth and $\mathrm{N}$ leaching to systematic variations in temperature and precipitation using a dynamic crop model (Daisy). The resulting response surface is then combined with probabilistic projections of $\mathrm{CC}$ for different 
future periods. The uncertainty of future $\mathrm{CC}$, represented by probabilistic projections, was found to be the dominating source of the uncertainty in simulations of yield and $\mathrm{N}$ leaching. Different methodologies to apply seasonal CC projections to produce impact response surfaces were tested and estimates of uncertainties in projected grain yield and leaching were obtained. Compared to the $\mathrm{CC}$ projections themselves, the methods of applying projections had only a minor effect on $\mathrm{N}$ leaching and grain yield. We found that the uncertainty in CC had a higher impact on LS soil than on $\mathrm{S}$ soils due to generally higher yield levels for LS soils. Winter wheat grain yields were projected to decline over time and $\mathrm{N}$ leaching to increase. Probability of high grain yield reductions and low $\mathrm{N}$ leaching followed the trends in mean yields and mean $\mathrm{N}$ leaching.

\section{Appendix A}

The photosynthesis in Daisy is calculated using a light saturation response curve. However, the effect of $\mathrm{CO}_{2}$ concentration is not included in the standard Daisy model. The response of light saturated photosynthesis rate $\left(F_{m}\right)$ and initial light use efficiency $(\varepsilon)$ to atmospheric $\mathrm{CO}_{2}$ concentration was calculated from Goudriaan et al. (1985):

$F_{\mathrm{m}}=\frac{C_{\mathrm{a}}-\Gamma}{C_{\mathrm{r}}-\Gamma} g_{C} F_{\mathrm{mr}}$

$\varepsilon=\frac{C_{\mathrm{a}}-\Gamma}{C_{\mathrm{a}}+2 \Gamma} \varepsilon_{0}$

where $C_{\mathrm{a}}$ is the atmospheric $\mathrm{CO}_{2}$ concentration (ppm), $C_{\mathrm{r}}$ is the reference $\mathrm{CO}_{2}$ concentration, which is set to $353 \mathrm{ppm}$ corresponding to the average atmospheric $\mathrm{CO}_{2}$ concentration in 1990 (Houghton et al., 2001), $\Gamma$ is the $\mathrm{CO}_{2}$ compensation point $(\mathrm{ppm}), F_{m r}$ is the light saturated photosynthesis rate at the reference $\mathrm{CO}_{2}$ concentration, and $\varepsilon_{0}$ is the reference initial light use efficiency.

The $\mathrm{CO}_{2}$ compensation point depends on temperature. However, $\Gamma$ was set to 25 corresponding to $18^{\circ} \mathrm{C}$ (Medlyn et al., 1999). $\varepsilon$ was set to $0.05 \mathrm{~g} \mathrm{CO}_{2} \mathrm{~W}^{-1} \mathrm{~h}^{-1}$ at $353 \mathrm{ppm}$, giving a $\varepsilon_{0}$ of $0.0615 \mathrm{~g} \mathrm{CO}_{2} \mathrm{~W}^{-1} \mathrm{~h}^{-1}$. $F_{\mathrm{m}}$ was assumed to be optimal at temperatures from 10 to $25^{\circ} \mathrm{C}$ and to decline linearly with temperature from 25 to $35^{\circ} \mathrm{C}$. The increase in $F_{\mathrm{m}}$ was linear with temperatures from 2 to $10^{\circ} \mathrm{C}$. $F_{\mathrm{mr}}$ was assumed to depend on specific leaf area index (Penning de Vries et al., 1989), and set to $5 \mathrm{~g} \mathrm{CO}_{2} \mathrm{~m}^{-2} \mathrm{~h}^{-1}$.

$g_{\mathrm{C}}$ is the ratio of stomatal conductance at $C_{\mathrm{a}}$ relative to $C_{\mathrm{r}}$. This functional response of $g_{\mathrm{C}}$ to changes in atmospheric $\mathrm{CO}_{2}$ concentration was estimated based on data from soybean (Ainsworth et al., 2002) and wheat (Kimball et al., 2002):

$g_{\mathrm{C}}=0.3+247 / C_{\mathrm{a}}$
The photosynthesis in Daisy is reduced if the $\mathrm{N}$ concentration in green leaves is below a critical level. The minimum, maximum and critical $\mathrm{N}$ concentrations of all vegetative plant organs were all reduced by $20 \%$ for a doubling of $\mathrm{CO}_{2}$ concentration (Soussana et al., 1996). The shape of the response curve was assumed to be the same as for stomatal conductance:

$\alpha=0.6+141 / C_{\mathrm{a}}$

where $\alpha$ is the relative effect of $\mathrm{CO}_{2}$ on $\mathrm{N}$ concentrations.

The specific leaf area will also be reduced with increasing $\mathrm{CO}_{2}$ concentration. However, this response is slightly less than for $\mathrm{N}$ concentrations (Wand et al., 1999; Kimball et al., 2002), and the following function was used:

$\beta=0.67+117 / C_{\mathrm{a}}$

where $\beta$ is the relative effect of $\mathrm{CO}_{2}$ on specific leaf area.

The potential transpiration was reduced with increasing $\mathrm{CO}_{2}$ concentrations according to the function proposed by Olesen et al. (2000). This relation reduced the transpiration by about $10 \%$ for a doubling of current atmospheric $\mathrm{CO}_{2}$ concentration.

Acknowledgements. We thank Glen Harris, Met Office Hadley Centre, for providing probabilistic climate change projections. This work was conducted within the EU FP6 ENSEMBLES project (contract GOEC-CT-2003-505539).

Edited by: T. Carter

Reviewed by: two anonymous referees

\section{References}

Abrahamsen, P. and Hansen, S.: Daisy: an open soil-cropatmosphere system model, Environ. Model. Softw., 15, 313-330, 2000.

Ainsworth, E. A. and Long, S. P.: What have we learned from 15 years of free-air $\mathrm{CO}_{2}$ enrichment (FACE)? A meta-analytic review of the responses of photosynthesis, canopy properties and plant production to rising $\mathrm{CO}_{2}$, New Phytol., 165, 351-372, 2005.

Ainsworth, E. A., Davey, P. A., Bernacchi, C. J., Dermody, O. C., Heaton, E. A., Moore, D. J., Morgan, P. B., Naidu, S. L., Yoora, H.-S., Zhu, X. G., Curtis, P. S., and Long, S. P.: A meta-analysis of elevated $\left[\mathrm{CO}_{2}\right]$ on soybean (Glycine max) physiology, growth and yield, Global Change Biol., 8, 695-709, 2002.

Allerup, P., Madsen, H., and Vejen, F.: (Danish report) Standardværdier (1961-90) af nedbørskorrektion, DMI Technical Report, 98-110, 1998

Bazot, S., Blum, H., and Robin, C.: Nitrogen rhizodeposition assessed by a $\left(\mathrm{NH}_{3}\right)-\mathrm{N}^{15}$ shoot pulse-labelling of Lolium perenne L. grown on soil exposed to 9 years of $\mathrm{CO}_{2}$ enrichment, Env. Exp. Bot., 63, 410-415, 2008.

Berntsen, J., Petersen, B. M., and Olesen, J. E.: Simulating trends in crop yield and soil carbon in a long-term experiment - effects of rising $\mathrm{CO}_{2}, \mathrm{~N}$ deposition and improved cultivation, Plant Soil, 287, 235-245, 2006. 
Bruun, S., Christensen, B. T., Hansen, E. M., Magid, J., and Jensen, L. S.: Calibrating and validation of the soil organic matter dynamics of the Daisy model with data from the Askov long-term experiments, Soil Biol. Biochem., 35, 67-76, 2003.

Challinor, A. J., Ewert, F., Arnold, S., Simelton, E., and Fraser, E.: Crops and climate change: progress, trends, and challenges in simulating impacts and informing adaptation, J. Exp. Bot. 60, 2775-2789, 2009.

Challinor, A. J., Wheeler, T. R., Slingo, J. M., Craufurd, P. Q., and Grimes, D. I. F.: Design and optimisation of a large-area processbased modelfor annual crops, Agric. Forest Meteorol. 124, 99120, 2004.

de Willegen, P.: $\mathrm{N}$ turnover in the soil-crop system. Comparison of fourteen simulation models, Fert. Res., 27, 141-149, 1991.

Diekkrüger, B., Söndgerath, D., Kersebaum, K. C., and McVoy, C. W.: Validity of agroecosystem models. A comparison of results of different models applied to the same dataset, Ecol. Model., 81, 3-29, 1995.

Eckersten, H., Blombäck, K., Kätterer, T., and Nyman, P.: Modelling $\mathrm{C}, \mathrm{N}$, water and heat dynamics in winter wheat under climate change in Southern Sweden, Agric. Ecosys. Environ., 86, 221-35, 2001.

Fuhrer, J.: Agroecosystem responses to combinations of elevated $\mathrm{CO}_{2}$, ozone, and global climate change, Agric. Ecosyst. Environ., 97, 1-20, 2003.

Genovese, G.: Methodology of the MARS Crop Yield Forecasting System, EUR-report 21291 EN, 2004.

Ghaffari, A., Cook, H. F., and Lee, H. C.: Climate change and winter wheat management: A modelling scenario for South-Eastern England, Clim. Change, 55, 509-533, 2002.

Goudriaan, J., van Laar, H. H., van Keulen, H., and Louwerse, W.: Photosynthesis, $\mathrm{CO}_{2}$ and plant production, in: Wheat growth and modelling, edited by: Day, W., Atkin, R. K., 107-122, NATO ASI Series, A Life Sciences, 86, New York, Plenum Press, 1985.

Hansen, S., Jensen, H. E., Nielsen, N. E., and Svendsen, H.: Simulation of nitrogen dynamics and biomass production in winter wheat using the Danish simulation model DAISY, Fert. Res., 27, 245-259, 1991.

Harris, G. R., Collins, M., Sexton, D. M. H., Murphy, J. M., and Booth, B. B. B.: Probabilistic projections for 21st century European climate, Nat. Hazards Earth Syst. Sci., 10, 2009-2020, doi:10.5194/nhess-10-2009-2010, 2010.

Harrison, P. A., Butterfield, R. E., and Orr, J. L.: Modelling climate change impacts on wheat, potato and grapevine in Europe, edited by: Downing, T. E., Harrison, P. A., Butterfield, R. E., and Lonsdale, K. G., in: Climate change, climatic variability and agriculture in Europe, Environmental Change Unit, University of Oxford, UK, 367-390, 2000.

Houghton, J. T., Ding, Y., Griggs, D. J., Noguer, M., van der Linden, P. J., Dai, X., Maskell, K., and Johnson, C. A.: Climate change 2001: The scientific basis. Contribution of working group I to the Third Assessment Report of the Intergovernmental Panel on Climate Change, Cambridge University Press, Cambridge, UK, 2001.

Jeppesen, E., Kronvang, B., Olesen, J. E., Audet, J., Søndergaard, M., Hoffmann, C. C., Andersen, H. E., Lauridsen, T. L., Liboriussen, L., Larsen, S. E., Beklioglu, M., Meerhoff, M., Özen, A., and Özkan, K.: Climate change effects on nitrogen loading from catchment: implications for nitrogen retention, ecological state of lakes and adaptation, Hydrobiologia, 663, 1-21, 2011.

Kimball, B. A., Kobayahsi, K., and Bindi, M.: Responses of agricultural crops to free-air $\mathrm{CO}_{2}$ enrichment, Adv. Agron., 77, 293368, 2002.

Kristensen, K., Waagepetersen, J., Børgesen, C. D., Vinther, F. P., Grant, R., and Blicher-Mathiesen, G.: Reestimation and further development of the model N-LES, N-LES 3 to N-LES 4 . DJF rapport Markbrug no. 139, Aarhus University, Tjele, Denmark, 2008.

Kristensen, K., Schelde, K., and Olesen, J. E.: Winter wheat yield response to climate variability in Denmark, J. Agric. Sci., 149, 33-47, 2011.

Kronvang, B., Jeppesen, E., Conley, D. J., Søndergaard, M., Larsen, S. E., Ovesen, N. B., and Carstensen, J.: Nutrient pressures and ecological responses to nutrient loading reductions in Danish streams, lakes and coastal waters, J. Hydrol., 304, 274-288, 2005 .

Kronvang, B., Windolf, J., Grant, R., Andersen, H. E., Thodsen, H., Ovesen, N. B., and Larsen, S. E.: Linking monitoring and modelling for river basin management: Danish experience with combating nutrient loadings to the aquatic environment from point and non-point sources, Sci. China Ser. E., 52, 3335-3347, 2009.

Kruijt, B., Witte, J. P. M., Jacobs, C. M. J., and Kroon, T.: Effects of rising atmospheric $\mathrm{CO}_{2}$ on evapotranspiration and soil moisture: A practical approach for the Netherlands, J. Hydrol., 349, 257267, 2008.

Long, S. P., Ainsworth, E. A., Leakey, A. D. B., Nösberger, J., and Ort, D. R.: Food for thought: Lower-than-expected crop yield stimulation with rising $\mathrm{CO}_{2}$ concentrations, Science, 312, 19181921, 2006.

Luo, Q. Y., Bellotti, W., Williams, M., Cooper, I., and Bryan, B.: Risk analysis of possible impacts of climate change on South Australian wheat production, Clim. Change, 85, 89-101, 2007.

Maracchi, G., Sirotenko, O., and Bindi, M.: Impacts of present and future climate variability on agriculture and forestry in the temperate regions: Europe, Clim. Change, 70, 117-135, 2005.

Medlyn, B. E., Badeck, F.-W., de Pury, D. G. G., Barton, C. V. M., Broadmeadow, M., Ceulemans, R., de Angelis, P., Forstreuter, M., Jach, M. E., Kellomäki, S., Laitat, E., Marek, M., Philippot, S., Rey, A., Strassemeyer, J., Laitinen, K., Liozon, R., Portier, B., Roberntz, P., Wang, K., and Jarvis, P. G.: Effects of elevated $\left[\mathrm{CO}_{2}\right]$ on photosynthesis in European forest species: a metaanalysis of model parameters, Plant Cell Environ., 22, 1475$1495,1999$.

Mearns, L. O., Hulme, M., Carter, T. R., Leemans, R., Lal, M., and Whetton, P.: Climate scenario development, in: Climate Change 2001: The Scientific Basis. Contribution of Working Group I to the Third Assessment Report of the Intergovernmental Panel on Climate Change, edited by: Houghton, J. T., Ding, Y., Griggs, D. J., Noguer, M., van der Linden, P. J., Dai, X., Maskell, K. and Johnson, C. A.,Cambridge University Press, Cambridge and New York, 739-768, 2001.

Murphy, J. M., Booth, B. B. B., Collins, M., Harris, G. R., Sexton, D. M. H., and Webb, M. J.: A methodology for probabilistic predictions of regional climate change from perturbed physics ensembles, Phil. Trans. R. Soc. A, 365, 1993-2028, 2007.

Murphy, J. M., Sexton, D. M. H., Jenkins, G. J., Boorman, P. M., Booth, B. B. B., Brown, C. C., Clark, R. T., Collins, M., Harris, G. R., Kendon, E. J., Betts, R. A., Brown, S. 
J., Howard T. P., Humphrey, K. A., McCarthy, M. P., McDonald, R. E., Stephens, A., Wallace, C., Warren, R., Wilby, R., and Wood, R. A.: UK Climate Projections Science Report: Climate change projections, Met Office Hadley Centre, Exeter, UK, http://ukclimateprojections.defra.gov.uk/content/view/ 824/517/, 2009.

Olesen, J. E. and Bindi, M.: Consequences of climate change for European agricultural productivity, land use and policy, Eur. J. Agron., 16, 239-262, 2002.

Olesen, J. E., Jensen, T., and Petersen, J: Sensitivity of field-scale winter wheat production in Denmark to climate variability and climate change, Clim. Res., 15, 221-238, 2000.

Olesen, J. E., Rubæk, G., Heidmann, T., Hansen, S., and Børgesen, C. D.: Effect of climate change on greenhouse gas emission from arable crop rotations, Nutr. Cycl. Agroecosyst., 70, 147-160, 2004.

Olesen, J. E., Carter, T. R., Diaz-Ambrona, C. H., Fronzek, S., Heidmann, T., Hickler, T., Holt, T., Minguez, M. I., Morales, P., Palutikov, J., Quemada, M., Ruiz-Ramos, M., Rubæk, G., Sau, F., Smith, B., and Sykes, M.: Uncertainties in projected impacts of climate change on European agriculture and ecosystems based on scenarios from regional climate models, Clim. Change, 81, 123-143, 2007.

Olesen, J. E., Trnka, M., Kersebaum, K. C., Skjelvåg, A. O., Seguin, B., Peltonen-Saino, P., Rossi, F., Kozyra, J., and Micale, F.: Impacts and adaptation of European crop production systems to climate change, Eur. J. Agron., 34, 96-112, 2011.

Patil, R., Lægdsmand, M., Olesen, J. E., and Porter, J. R.: Soil warming affected growth and development of winter wheat, but not yield, J. Agric. Sci., 148, 553-566, 2010.

Patil, R. H., Lægdsdmand, M., Olesen, J. E., and Porter, J. R.: Sensitivity of crop yield and $\mathrm{N}$ losses in winter wheat to changes in mean and variability of temperature and precipitation in northern Europe using the FASSET model, Acta Agric. Scand. Sect. B. Soil Plant Sci., in press, 2011.

Penning de Vries, F. W. T., Jansen, D. M., ten Berge, H. F. M., and Bakema, A.: Simulation of ecophysiological processes of growth in several annual crops, Wageningen, NL: Pudoc, 1989.

Penman, H. L.: Evaporation: an introductory survey, Neth. J. Agric. Sci., 4, 9-29, 1956.

Rustad, L. E., Campbell, J. L., Marion, G. M., Norby, R. J., Mitchell, M. J., Hartley, A. E.: A meta-analysis of the response of soil respiration, net nitrogen mineralization, and above-ground plant growth to experimental ecosystem warming, Oecologia, 126, 543-562, 2001.
Simmelsgaard, S. E.: The effect of crop, N-level, soil type and drainage on nitrate leaching from Danish soils, Soil Use Manage, 14, 30-36, 1998.

Smith, P., Smith, J. U., Powlson, D. S., Mcgill, W. B., Arah, J. R. M., Chertov, O. G., Coleman, K., Franko, U., Frolking, S., Jenkinson, D. S., Jensen, L. S., Kelly, R. H., Klein-Gunnewiek, H., Komarov, A. S., Li, C., Molina, J. A. E., Mueller, T., Parton, W. J., Thornley, J. H. M., and Whitmore, A. P.: A comparison of the performance of nine soil organic matter models using datasets from seven long-term experiments, Geoderma, 81, 153225, 1997.

Soussana, J. F. and Lüscher, A.: Temperate grasslands and global atmospheric change: a review, Grass Forage Sci., 62, 127-134, 2007.

Soussana, J. F., Casella, E., and Loiseau, P.: Long-term effects of $\mathrm{CO}_{2}$ enrichment and temperature increase on a temperate grass sward. II., Plant nitrogen budgets and root fraction, Plant Soil, 182, 101-114, 1996.

Sowerby, A., Blum, H., and Ball, A. S.: Elevated atmospheric $\mathrm{CO}_{2}$ affects the turnover of nitrogen in a European grassland, Appl Soil Ecol., 28, 37-46, 2005.

Thomsen, I. K., Lægdsmand, M., and Olesen, J. E.: Crop growth and nitrogen turnover under increased temperatures and low autumn and winter light intensity, Agric. Ecosyst. Environ, 139, 187-194, 2010.

Turner, M. M. and Henry, H. A. L.: Net nitrogen mineralization and leaching in response to warming and nitrogen deposition in a temperate old field: the importance of winter temperature, Oecologia, 162, 227-236, 2010.

van Ittersum, M. K., Howden, S. M., and Asseng, S.: Sensitivity of productivity and deep drainage of wheat cropping systems in a Mediterranean environment to changes in $\mathrm{CO}_{2}$, temperature and precipitation, Agric. Ecosyst. Environ., 97, 255-273, 2003.

Wand, S. J. E., Midgley, G. F., Jones, M. H., and Curtis, P. S.: Responses of wild $\mathrm{C} 4$ and $\mathrm{C} 3$ grass (Poaceae) species to elevated atmospheric $\mathrm{CO}_{2}$ concentrations: a meta-analytic test of current theories and perceptions, Global Change Biol. 5, 723-741, 1999.

Wolf, J., Evans, L. G., Semenov, M. A., Eckersten, H., and Iglesias, A.: Comparison of wheat simulation models under climate change. I. Model calibration and sensitivity analyses, Clim. Res., 7, 253-270, 1996. 